\title{
EXTRADITION AND MENTAL HEALTH IN UK LAW
}

\begin{abstract}
The response of UK extradition law and practice to requested persons presenting with mental health disorders is multi-faceted and unnecessarily complex. There are a number of reasons for this. They centre upon the law failing to adequately recognise that mental health cases can give rise to concerns not present in physical health cases. The deficiencies of the law are found in the three applicable bars to extradition; oppression, human rights and forum. They also can be seen in the applicable rules of evidence and the practice of diplomatic assurances. The time has come for UK law to specifically and systematically respond to mental health disorders in the context of extradition.
\end{abstract}

\section{INTRODUCTION}

The response of UK extradition law and practice to requested persons presenting with mental health disorders is multi-faceted and unnecessarily complex. The issues raised are not consistently addressed. The reasons for this are manifold and inter-related. They are firstly that extradition law fails to adequately recognise that mental health cases can engender distinct concerns. This is seen in the similarity in approach taken to deportation and physical illness on the one hand and mental health disorders on the other. It is also manifest in the operation of the three different, intricate and at times overlapping bars which may prevent an extradition in mental health cases. The response to the evidential challenges arising in the area further illustrates the deficiency of the law. Secondly, where the law has specifically recognised that mental health cases may be distinct that acceptance is wanting. This recognition has occurred where requested persons may be at risk of suicide and within the substance of diplo-

\footnotetext{
* Paul Arnell, Law School, Robert Gordon University, Garthdee Road, Aberdeen AB107QE, Scotland. E-mail: p.arnell@rgu.ac.uk.

* * The author wishes to thank Professor Clive Walker and the anonymous referees for their comments on an earlier draft. The usual disclaimer applies.
} 
matic assurances, including where an individual may be unfit to plead. The law here has developed a bespoke set of "suicide-case" rules and employed diplomatic assurances in response to some of the concerns. Whilst positive, these developments are inadequate and inconsistent. Overall, the deficient nature of the law arises from its failure to systematically recognise and coherently address the concerns that often arise in mental health cases. This article analyses the response of UK extradition law to mental health disorders and uncovers the reasons behind its deficiencies. In doing so it brings to the fore the steps needed to address the weaknesses in the law. The applicable law and jurisprudence including the notable cases of Shiren Dewani, ${ }^{1}$ Lauri Love $^{2}$ and Haroon Aswat $^{3}$ are described and analysed in this task. The article concludes by bringing together the suggestions of how the law might be amended so that it responds more appropriately to requested persons with mental health disorders. ${ }^{4}$

\section{EXTRADITION LAW}

Extradition is a process whereby accused and convicted persons are lawfully transferred from one territory to another for trial or, if al-

\footnotetext{
${ }^{1}$ South Africa v Dewani [2012] EWHC 842 (Admin), South Africa v Dewani (No 2) [2014] EWHC 153 (Admin) and Dewani v South Africa [2014] EWHC 770 (Admin).

${ }^{2}$ US v Love [2016] Lloyd's Rep. F.C. 597 and Love v US [2018] EWHC 172 (Admin).

${ }^{3}$ Ahmad v US [2006] EWHC 2927 (Admin), Aswat v UK (No 1) (2014) 58 EHRR $1, R$ (on the application of Aswat) $v$ Secretary of State [2014] EWHC 1216 (Admin, $R$ (on the application of Aswat) v Secretary of State [2014] EWHC 3274 (Admin), and Aswat v UK, Ap. No. 621/76/14, 6 January 2015, cited at https://hudoc.echr.coe.int/ eng\#.

4 "Mental health disorder" is used throughout this article in a lay sense as a general description of both mental health conditions and developmental disorders. It is not suggested that mental and physical illnesses per se are existentially different, rather that the former can give rise to concerns in the context of extradition that the latter does not. Refuting the view that mental and physical illnesses are distinct generally is Kendell, R.E., The Distinction between Mental and Physical Illness, (2001) 178 British Journal of Psychiatry 490. Discussing the various models or paradigms of understanding psychological abnormality, reflecting the differences in understanding, is Comer, R.J., Abnormal Psychology, Tenth Edition, Worth Publishers, New York, 2018, chapter 3.
} 
ready convicted, punishment. ${ }^{5}$ It is largely governed in the UK by the Extradition Act 2003 (2003 Act) and internationally by the European Arrest Warrant (EAW) and bilateral extradition treaties. ${ }^{6}$ The 2003 Act contains separate provision for EU and non-EU extraditions. The main differences in law between the two are that under the EAW there is an absence of political participation in the process and the Framework List of offences can act to satisfy the double criminality requirement. Practically, the EAW has led to a material increase in the volume of UK-EU surrenders, which in turn has given rise to a considerable jurisprudence. Extradition jurisprudence, under the EAW or otherwise, arises from the fact that when an extradition request is made to the UK a hearing must take place where a number of bars may be put forward in opposition. If accepted by the judge, the extradition will not proceed, or be adjourned. There are three bars in the 2003 Act that can act to stop an extradition on the basis of a mental health disorder. They are based on oppression and injustice, human rights and forum. ${ }^{7}$ The law sets high hurdles that must be met for an extradition to be prevented under the bars. This is a consequence of both their terms per se and their judicial interpretation. Recognition and consideration of mental health disorders in extradition law is relatively novel. Legislatively, mental health was referred to for the first time in the 2003 Act. Mental health extradition jurisprudence began to emerge around the same time, firstly in the case law of the ECtHR.

\footnotetext{
${ }^{5}$ Requests can therefore be either "accusation" or "conviction". See generally the House of Lords Select Committee on Extradition Law, Extradition: UK Law and Practice, 10 March 2015, cited at https://publications.parliament.uk/pa/ld201415/ ldselect/ldextradition/126/126.pdf and $A$ Review of Extradition, published in September 2011 (the Baker Review), cited at https:/www.gov.uk/government/up loads/.../extradition-review.pdf.

${ }^{6}$ The basis of the EAW is a 2002 Framework Decision, cited at https://eur-lex. europa.eu/legalcontent $/ \mathrm{EN} / \mathrm{TXT} /$ ?uri $=$ celex $\% 3 \mathrm{~A} 32002 \mathrm{~F} 0584$. It is noteworthy that the terms of the EAW itself, the Charter of Fundamental Rights and jurisprudence of the Court of Justice of the European Union (CJEU) have not, to date, had a material effect upon UK extradition law in the area of mental health. Instead the law is almost exclusively organic to the UK, and influenced by the jurisprudence of the European Court of Human Rights (ECtHR). Outside the EU the UK has extradition agree ments with over 100 states and territories, see https://www.gov.uk/guidance/extra dition-processes-and-review.

${ }^{7}$ For the purposes of this article "bar" will include all grounds which may prevent an extradition.
} 


\section{EXTRADITION AND DEPORTATION}

Providing background and context to the response of extradition law to mental health disorders are deportation and physical ill-health extradition jurisprudence. This follows the affinity between extradition and deportation and the general conflation of mental and physical illness by extradition law. For our present purposes, the main relevance of deportation is found the application of human rights law. In Balodis-Klocko v Latvia it was held that there is no distinction between the immigration line of authority and that of extradition in the application of human rights. ${ }^{9}$ A second relevance of deportation is that diplomatic assurances are relied upon to address human rights concerns where it is proposed, as with extradition. This relevance noted, it should not be forgotten that extradition and deportation differ in their origins, purposes and applicable law. A request from a third territory forms the origin of an extradition while a deportation is founded upon a UK decision to expel an individual from its territory. The purpose of (outgoing) extradition is a prosecution or imposition of a sentence abroad. Deportation acts to serve the UK public good. Legally, extradition is generally governed by the 2003 Act and, in England and Wales, the Criminal Procedure Rules ${ }^{10}$ and the Extradition Act 2003 Police Codes of Practice. ${ }^{11}$ Deportation is governed by the Immigration Acts, the Immigration Rules ${ }^{12}$ and a collection of Home Office Guides. ${ }^{13}$ It is worth keeping these facts in mind when deportation cases are relied upon or referred to in extradition cases. Indeed, an argument can be made that in light of the considerable differences between the two processes that there is a greater distinction between them, especially in mental health cases.

\footnotetext{
${ }^{8}$ [2014] EWHC 2661 Admin.

${ }^{9}$ Ibid at para 18.

${ }^{10}$ Part 50 of the Criminal Procedure Rules applies to extradition, at https://www. justice.gov.uk/courts/procedure-rules/criminal/docs/2015/crim-proc-rules-2015-part50.pdf. A further difference between extradition and deportation is that UK nationals cannot be deported.

${ }^{11}$ Found at https://www.gov.uk/government/publications/extradition-act-2003police-codes-of-practice.

12 "Immigration Acts", defined by s 61 of the Borders Act 2007 includes ten statutes starting with the Immigration Act 1971. Part 13 of the Immigration Rules govern deportation, at https://www.gov.uk/guidance/immigration-rules/immigra tion-rules-part-13-deportation.

${ }^{13}$ A number of which are found here https://www.gov.uk/topic/immigration-op erational-guidance/modernised-guidance.
} 


\section{EXTRADITION AND HEALTH GENERALLY}

Ill-health, mental and physical, has been a basis upon which an extradition can be prevented for a relatively short time. It was the ground upon which the extradition of Augusto Pinochet to Spain was blocked in $2000 .{ }^{14}$ In part due to the controversy engendered by that case the extent of political discretion in extradition cases to cover illhealth was limited and ss 25 and 91 were inserted into the 2003 Act. Termed the "lex specialis" 15 in cases of ill-health generally the sections prevent an extradition where it is oppressive or unjust on the basis of the physical or mental condition of the requested person (hereinafter the oppression bar). If an argument is accepted under the bar the requested person is discharged or his hearing is adjourned. Illustrating the difficulty in meeting the bar and the range of relevant considerations where physical health is put forward is Blaszak $v$ Poland. ${ }^{16}$ Blaszak was sought on a conviction warrant. Subsequent to his sentence he suffered a stroke which left him with limited strength, movement, speech and memory. He became epileptic and suffered from regular seizures. He sought to rely on s 25 . The court considered not only his ill-health and prognosis but also the relevant safeguards and conditions under the law and in the prisons in Poland. These were considered in light of certain presumptions arising from Poland's membership of the EU and the ECHR - in essence that it would adhere to its legal obligations. ${ }^{17}$ The Court also assessed Blaszak's culpability and offences. The "exceptionally high bar" applying when ill-health was put forward in opposition to imprisonment within the UK was held to apply to extradition and his appeal against extradition was refused. ${ }^{18}$

The human rights bar, a second ground which may cover illhealth, is also difficult to satisfy and can entail judicial consideration of disparate factors. Two human rights are most commonly put forward, found in articles 3 and 8 of the European Convention of Human Rights (ECHR). The former prohibits torture and inhuman and degrading treatment and punishment and the latter guarantees respect for private and family life. Demonstrating the high bar is the

\footnotetext{
${ }^{14}$ See http://news.bbc.co.uk/1/hi/uk/663886.stm.

${ }^{15}$ So designated in Surico v Italy [2018] EWHC 401 (Admin) at para 31.

16 [2016] EWHC 2412 (Admin).

${ }^{17}$ Ibid at para 15.

${ }^{18}$ Arguments on the basis of human rights were also made and rejected.
} 
leading article 3 physical ill-health case of $N v U K .{ }^{19}$ Here the UK sought to deport $\mathrm{N}$ to Uganda. She was receiving treatment for Aids. The Grand Chamber of the ECtHR held that aliens could not in principle claim any entitlement to remain in a state party in order to continue to benefit from medical, social or other forms of assistance and services. A violation of article 3, it held, will not be established even if the expulsion would interrupt treatment, lead to a deterioration in health or increase morbidity. ${ }^{20}$ The height of the bar in article 3 cases is such that it is limited to so-called "deathbed" cases. ${ }^{21}$ What needs to be emphasised about extradition and health generally are that human rights and oppression may act as a bar, a high hurdle must be met to prevent an extradition under them, and that a wide range of factors are considered by courts when they are put forward. Further and notably, courts have not systematically recognised and considered the distinct issues that may arise where the disorder is one of mental as opposed to physical health. It is suggested that this recognition is called for.

\section{EXTRADITION AND MENTAL HEALTH}

A first point to address in considering extradition and mental health within the UK is the scale of persons extradited generally, the percentage of those who put forward mental health disorders and the types of those disorders. The information available for each is these is very limited and/or anecdotal. It is clear, though, that the scale of extradition and surrender is significant, particularly under the EAW. In the calendar year 2016 the UK received 13,797 EAW requests and surrendered 1431 individuals to fellow EU member states. ${ }^{22}$ Outside

${ }^{19}$ [2008] 47 EHRR 39. See Battjes, H., In Search of a Fair Balance: the Absolute Character of the Prohibition of Refoulment under Article 3 Reassessed, (2009) 22(3) Leiden Journal of International Law 538.

${ }^{20}$ A factually similar extradition case is Dzgoev $v$ Russia [2017] EWHC 735 (Admin). Here an argument based on article 3 was rejected where Dzgoev was suffering from Aids and hepatitis $\mathrm{C}$ regardless of whether extradition would interrupt treatment, lead to a deterioration in his condition or increase morbidity. A leading article 8 extradition and physical health case is Norris v USA [2010] UKSC 9. See further Stephen, C., We Want You: Extradition in the UK Supreme Court, (2011) 15(1) Edinburgh Law Review 133.

${ }^{21}$ See, for example, SL (St Lucia) v Secretary of State [2018] EWCA Civ 1894, at para 19 .

${ }^{22}$ The National Crime Agency collates EAW statistics, at http://www.national crimeagency.gov.uk/publications/european-arrest-warrant-statistics. The NCA is 
the EU the number is considerably smaller, in the financial year 2012-2013 84 requests from Category 2 territories were made to England and Wales. ${ }^{23}$ The number of requested persons who were actually extradited over this period is not available. Nor is the number of requested persons who put forward mental health disorders as a bar to extradition, and the fate of such arguments. Anecdotally, however, it can be assumed that the number of cases where mental health arguments are made is not insignificant. A considerable number of reported extradition cases contain mental health-related arguments - these form the basis of the analysis below. As to the mental health disorders affecting requested persons, again there is no available information. From the present research, however, persons with autism, and in particular Asperger's Syndrome are prominent. Other disorders forming the basis of arguments against extradition have included paranoid schizophrenia, depression, and post-traumatic stress disorder. In Howes $v H_{M A}{ }^{24}$ a leading case in Scotland on the issue, the requested person was diagnosed with an adjustment disorder with the predominant symptoms of anxiety, panic attacks and compulsive behaviour. Overall, the only point that can be made certainty is that there is a near complete dearth of empirical information in the area. That noted, the response of extradition law to mental health disorders is clear, albeit unsatisfactorily so.

The failure of the law to consistently and adequately consider the unique issues in mental health cases is seen in the operation and terms of the oppression and human rights bars. Recognising those issues, in the context of article 3, has been the Court of Appeal where it stated: "There has been some debate in our domestic case-law as to the extent to which cases of mental illness... are analogous to cases of physical illness for the purposes of the application of article 3 . Whilst there may be factual differences between the two types of case... the

\footnotetext{
Footnote 22 continued

now the UK's "Central Authority" under the EAW Framework Decision. The considerable disparity between requests and surrenders is not explained in the statistics. Amongst the reasons however, are the policies of some states, notably Poland, to issue requests for all alleged crimes and sentences and the NCA does not certify the request for reasons of proportionality or legal validity. It is not explained in any material sense by courts in the UK refusing surrender or extradition. Judicial refusals are exceptional.

${ }^{23}$ The House of Lords Select Committee on Extradition Law, supra note 5 at p 38.

${ }^{24} 2010$ SLT 337 so described in Wlodarczyk v Lord Advocate [2012] HCJAC 41 at para 34.
} 
same principles are to be applied to them both". ${ }^{25}$ Confirming the general lack of differentiation between mental and physical cases are the terms of the oppression bar. Section 25(2) inter alia provides that an extradition is barred, or should be adjourned, where the extradition judge finds that "... the physical or mental condition of the person... is such that it would be unjust or oppressive to extradite him". The same law applies in spite of mental and physical health cases being - to an extent at least - factually dissimilar. It is not suggested, of course, that the law must explicitly accommodate, legislatively or judicially, all factually distinct cases - this is impossible. It is argued, however, that mental health extradition cases do merit a degree of systematically bespoke legal consideration because of the scale of difference between them, including a number of issues that arise in mental health cases that do not in physical health cases. Further, it is suggested that where differentiation has taken place it has been inconsistent and inadequate.

The factual differences between mental and physical health disorders in the context of extradition are such to merit an element of differentiation under the law. This is not to suggest that there are not similarities between them. Medical treatment is necessary in both. Arguments based upon the importance of the care one is receiving within the UK, the effect of its withdrawal, and the lesser nature of the medical treatment and facilities in the requesting state can therefore be made in each. As to the latter the ECtHR stated in $N v$ $U K$ :

\footnotetext{
"The decision to remove an alien who is suffering from a serious mental or physical illness to a country where the facilities for the treatment of that illness are inferior to those available in the contracting state may raise an issue under Art.3, but only in a very exceptional case, where the humanitarian grounds against the removal are compelling". ${ }^{26}$
}

It is clear that both types of illness may call for medical facilities and/ or drugs which may be available in the UK and not, or to a lesser extent, in the requesting state. ${ }^{27}$ To this extent mental and physical

\footnotetext{
${ }^{25}$ RA (Sri Lanka) v Secretary of State for the Home Department, [2008] EWCA Civ 1210, at para 49.

${ }^{26}$ Supra note 19 at para 42.

${ }^{27}$ A difference in the type and availability of drugs used in treating schizophrenia was considered in Bensaid v UK (2001) 33 EHRR 10. The case, one of the leading mental health precedents, is discussed below.
} 
health disorders are rightfully treated similarly. There are differences between the two, however, in both degree and substance.

The underlying commonalities between mental and physical health extradition cases only go so far. There are issues which are attendant to mental health cases alone. Further, there are factors present in both which can be particularly pronounced within mental health cases. The latter arise from the fact that the process of extradition, including a foreign trial, detention and perhaps imprisonment, and indeed the transfer itself, is often likely to have a greater effect upon someone suffering from a mental illness than otherwise. In other words, the dislocation and hardship that all persons subjected to extradition experience may be considerably exacerbated for persons suffering from certain mental illnesses. This was held to be the case in Love $v$ US, discussed below. Related to this is the likely enhanced effect of an extradition upon an individual with a mental health disorder due to the necessary separation from his home, family and support network in the UK. These differences between mental and physical cases are a matter of degree. The same circumstances befall those with mental and physical health disorders but it is more likely that they will have a greater impact on the former. More relevant in setting mental health cases apart from physical cases are the distinct issues that arise in them alone. These are particular evidential considerations, the risk of suicide and the fitness to plead of the requested person. Each of these issues will be specifically discussed below. Firstly, however, the failings of extradition law more generally as regards mental health will be exposed through a description and analysis of the three applicable bars to extradition. The inadequate and inconsistent recognition and accommodation of the differences between mental and physical health cases will be established. The weaknesses in the law will be seen to militate in favour of a rationalisation of the bars, in both application and number.

\section{THREE GERMANE BARS}

The three bars which may come into play where a requested person presents with a mental health disorder, oppression, human rights and forum, each have their own terms and jurisprudence. None of them were designed to specifically address mental health disorders. The bars are of different pedigree. The oldest is that based on oppression. Its origins are found in the Fugitive Offenders Act 1881. The newest is the forum bar, being inserted into the 2003 Act by the Crime and 
Courts Act 2013. Human rights as an explicit bar in UK law dates from 1 January 2004, when the 2003 Act entered into force. What the bars have in common, in addition to being applicable in mental health cases, is that they contribute to the complex and unsatisfactory response of the law in the area.

\subsection{Oppression and Injustice}

\subsubsection{Derivation and Meaning}

Sections 25 and 91 of the 2003 Act contain the oppression bar for Category 1 (EU) and 2 (generally non-EU) territories respectively. Kakis $v$ Government of the Republic of Cyprus ${ }^{28}$ is accepted as providing an authoritative interpretation of the words "oppression" and "injustice" in extradition. Here Lord Diplock stated "'Unjust' I regard as directed primarily to the risk of prejudice to the accused in the conduct of the trial itself, "oppressive" as directed to hardship to the accused resulting from changes in his circumstances that have occurred during the period to be taken into consideration; but there is room for overlapping, and between them they would cover all cases where to return him would not be fair". ${ }^{29}$ The adoption of this understanding, being made in the context of the passage of time under the Fugitive Offenders Act 1967, is not particularly useful. ${ }^{30}$ This is because it suggests that the passage of time is an operative consideration. However, time may, or may not, be a relevant factor. The bar requires a court to look at the fairness of extradition proceedings if a person is unfit as well as the consequences of extradition were it to take place. ${ }^{31}$ This includes taking into account conditions in both the UK at the time of the hearing and within the requesting state, speculatively, after extradition. Regard is to be had to "... all the relevant circumstances, including the fact that extradition is ordinarily likely to cause stress and hardship [that] will inevitably vary from case to case" ${ }^{32}$ Conditions in the requesting state need not

${ }^{28}$ [1978] 1 WLR 779.

${ }^{29}$ Ibid at $\mathrm{p} 782$. Within the UK jurisdictions somewhat similar pleas can be made in bar of trial. In Scotland, for example, oppression can be put forward where has there been prejudice so grave as to be incapable of being removed by an appropriate direction to the jury, or by other appropriate action on the part of the trial judge, so as to give the accused a fair trial. See Stuurman v HMA 1980 JC 111.

${ }^{30}$ It was adopted, inter alia, in South Africa $v$ Dewani, supra note 1 at para 74.

${ }^{31}$ Nicholls, C., et al, The Law of Extradition and Mutual Assistance, Third Edition, Oxford University Press, Oxford, para 5.114.

${ }^{32}$ South Africa v Dewani, supra note 1 at para 73. 
be similar to those within the UK, rather, the court seeks to ascertain whether the difference in treatment is such that extradition would be oppressive. ${ }^{33}$ Clearly, mental and physical disorders are not distinguished in general understandings of the bar.

\subsubsection{Burden and Standard of Proof and Threshold}

Critical to the operation of the bar are the burden of establishing it, the required standard of proof and the threshold at which courts hold it met. As regard the burden, it is clear that the onus falls upon the requested person to establish that it would be oppressive or unjust to extradite him because of his mental or physical health. The standard at which the burden is discharged is the balance of probabilities, although there is dicta to suggest that there is in fact a higher standard. ${ }^{34}$ As to the threshold, the law struggles to clearly and precisely set a test that must be met where courts can hold it successfully invoked. The law is that each case turns on its specific facts. In South Africa $v$ Dewani, for example, the court strongly discouraged the citation of previous decisions. ${ }^{35}$ A degree of judicial guidance on the requisite threshold is clearly needed, however. It is not difficult to find. In Howes v HMA the High Court of Justiciary stated "... in practice a high threshold has to be reached...". ${ }^{36}$ That height reflects countervailing considerations including the public interest in giving effect to treaty obligations in extradition cases and that the UK's extradition partners "... are likely to have adequate facilities available for treating the health problems of persons whose extradition is requested". 37

Whilst the height of the threshold is established the question of whether it is fixed or relative is not. This is relevant because if relative it could admit a degree of flexibility and accommodate differing circumstances. Mental and physical health cases, for example, could be distinguished. This is what happened in South Africa v Dewani. It was held that whilst an adjournment under s 91 was appropriate where a

\footnotetext{
${ }^{33} R$ (on the application of Mikolajczyk) v Poland [2010] EWHC 3503 (Admin) at para 16-17.

${ }^{34}$ In Griffin v France [2011] EWHC 943 (Admin) the High Court stated that the burden was perhaps to a higher standard, following that suggested by the ECtHR, at para 47. Whilst generally helpful in ensuring consistency, this view of the ECtHR is an example of the at times less than ideal effect of its jurisprudence.

35 South Africa v Dewani, supra note 1 at para 73.

${ }^{36}$ Supra note 24 at para 13.

${ }^{37}$ Ibid.
} 
person was recovering from an acute injury or physical illness because the prognosis for recovery was certain, "... in other cases where the quantification of the degree of risk to life is less certain and the prognosis is also less certain the interests of justice require consideration of that person being brought to trial". ${ }^{38}$ This is significant. It suggests that the threshold for an adjournment is in fact higher in mental health cases than physical health cases. Whether this also applies to a discharge is not stated. The court's reasoning was that the greater uncertainty in the risk to life and prognosis in mental health cases weighed in favour of extradition rather than against it. It is suggested that, in such circumstances, it is not unreasonable to come to the opposite conclusion - that in the face of greater uncertainty the threshold should lower, not rise.

\subsubsection{Mental and Physical Health Distinction}

There has been limited recognition of the distinction between mental and physical health cases under the oppression bar. As just seen, a higher threshold may attach to mental health cases than exists in physical cases. More significantly, the law has recognised that two particular issues merit especial consideration. These are fitness to plead and the risk of suicide. ${ }^{39}$ Fitness to plead cases arise where there is agreement on the matter at the extradition hearing; the position where there is disagreement will be mentioned below. ${ }^{40}$ In South Africa v Dewani, it was agreed Dewani was unfit for trial at the time of his appeal and that it was not known when he would be fit in the future. The Court had to decide whether it was oppressive or unjust to extradite in the circumstances. It held that it might be oppressive or unjust to extradite Dewani without considering whether an assurance should be required providing that he would be free to return to the UK after a specified period of time if he remained unfit. ${ }^{41}$ South Africa subsequently gave such an assurance (the period

\footnotetext{
${ }^{38}$ South Africa v Dewani, supra note 1 at paras 76-77.

39 The risk of suicide is discussed separately below because all three bars have been held to be applicable to it.

${ }^{40}$ For a discussion of fitness to plead in extradition in an intra-US context see Peil, J., et al, Determining a Criminal Defendant's Competency to Proceed With an Extradition Hearing, (2015) 43 Journal of the American Academy of Psychiatry and Law 201. See in regard to Gary McKinnon Mackenzie, R., and Watts, R., Injustice and Disabilities: the Case against the Extradition of Gary McKinnon to the USA, (2010) 15 Tizard Learning Disability Review 45.

${ }^{41}$ South Africa v Dewani (No 2), supra note 1, at paras 59-60.
} 
being 18 months) and Dewani was extradited. This development is one of a select number that have accommodated mental health disorders in extradition in a bespoke way. It has been applied inconsistently, however. Contrasting with South Africa v Dewani is Lord Advocate $v \mathrm{SN}^{42}$ where Sheriff Crowe exercised his discretion under $\mathrm{s}$ 71(2) of 2003 Act and refused to issue an arrest warrant where the requested person was found permanently unfit to plead and travel. Of more relevance and concern is the fact that there is no over-arching judicial, or indeed legislative, guidance on the practice of seeking fitness to plead assurances. In certain cases extradition has taken place in the absence of assurances where a requested person is unfit. The lack of guidance may give rise to inconsistency, and may operate to the detriment of requested persons. ${ }^{43}$

Whilst the law has come to accommodate fitness to plead and suicide cases under the oppression bar, it has not distinguished more generally between mental and physical health cases. The terms of the bar refer to them jointly and the jurisprudence provides that the likelihood of stress or hardship upon a requested person, whether he presents with physical or mental health concerns, is not normally relevant. ${ }^{44}$ Courts normally respond to mental disorders as they do to physical illness. In Boudhiba $v$ Central Examining Court, where a requested person suffered from a psychiatric disorder and low intelligence, the court stated:

"It is important, in my view, that the court should keep its eye firmly on the statutory question posed by section 25 . The question is not whether the appellant is suffering from a psychiatric disorder with or without the added disadvantage of low intelligence; it is whether, by reason of his mental condition it would unjust or oppressive to extradite him". 45

The accommodation of mental health disorders under the oppression bar, therefore, only goes so far.

42 [2017] SC EDIN 69.

${ }^{43}$ An example is Bobbe v Poland, [2017] EWHC 3161 (Admin). The position is discussed below under the heading of diplomatic assurances.

${ }^{44}$ Gomes v Trinidad and Tobago, [2009] 1 WLR 1038 at para 31. The case concerned the time bar, rather than ill-health.

45 [2006] EWHC 167 (Admin) at para 65. 


\subsection{Human Rights}

\subsubsection{Derivation and Meaning}

Human rights form the basis of the second bar that can apply in mental health cases. It is found in ss 21(1) and 87(1) of the 2003 Act. It provides that extraditions must be compatible with human rights. If they are not the requested person must be discharged. Significantly, the protection extends to possible future human rights violations within the requesting territory as well as those grounded in the UK ${ }^{46}$ The leading ECtHR mental health removal case is Bensaid $v U K{ }^{47}$ It established that a mental health disorder may form the basis of a human rights argument against removal. Bensaid inter alia argued his deportation would violate articles 3 and 8 because he would receive a lesser level of medical support in Algeria. The ECtHR began establishing the important point that article 3 could apply in a removal case even though the public authorities in Algeria were not directly or indirectly responsible. This is particularly relevant in health cases because requesting states may not "act" in the sense of doing or omitting to do something giving rise to the violation. That established, the ECtHR held that the less favourable Algerian circumstances were not decisive. The risks he faced were speculative (again a particularly germane point in mental health cases). There was not a sufficiently real risk that his removal would be contrary to article $3{ }^{48}$ Bensaid's article 8 was also rejected. Whilst the ECtHR held that mental health must be regarded as a part of private life, it was not established that Bensaid's moral integrity was affected so as to engage article 8 .

\subsubsection{Burden and Standard of Proof and Threshold}

The burden of proof under the human rights bar falls on the requested person. To meet the standard of proof he must establish that there is a real risk of a violation of his rights, meaning a " $\ldots$ risk which is substantial and not merely fanciful; and it may be established by something less than proof of a $51 \%$ probability". ${ }^{49}$ Once

\footnotetext{
46 The two loci of possible human rights violations have been designated foreign and domestic, by Lord Bingham in Ullah v Secretary of State, [2004] 2 AC 323 at para 9.

${ }^{47}$ Supra note 27.

48 Ibid at para 40.

${ }^{49}$ Brown v Rwanda [2009] EWHC 770 (Admin), at para 34. In $R$ (Lodhi) v Sec of State [2010] EWHC 567 (Admin) the court stated that "A real risk is more than a mere possibility but is less than a greater probability than not than an event would occur", at para 10 .
} 
this is met the burden shifts to the requesting state to establish that the violation will not take place. The court then is tasked with deciding whether the bar is satisfied. Affecting its decision is a presumption that the UK's extradition partners, particularly members of the Council of Europe and the EU, will respect human rights. ${ }^{50}$ The threshold test that a court applies turns upon the right in question. Under article 3 the court must find strong grounds for believing that there is a real risk the individual would be subjected to torture or inhuman treatment etcetera. ${ }^{51}$ Where article 6 is argued, the court must find that the requested person has suffered or risks suffering a flagrant denial of justice in the requesting state. ${ }^{52}$ Under article 8 the court must decide if the extradition unlawfully interferes with the person's respect for his private and family life. As a qualified right, courts must decide if the interference is prescribed by law, necessary in a democratic society and for one of the purposes stated in the article. The essence of this examination is whether the interference is outweighed by the public interest in extradition. ${ }^{53}$

\subsubsection{Mental and Physical Health Distinction}

Human rights jurisprudence has partially recognised a distinction between mental and physical health disorders in extradition. This development is relatively novel and largely confined to ECtHR case law. ${ }^{54}$ It is found in Ahmad $v U K^{55}$ and Aswat $v$ UK (No 1) ${ }^{56}$ In these cases, the ECtHR has in effect held that a degree of especial consideration of persons with mental health disorders is merited and that in such cases relatively specific mental-health related assurances may

${ }^{50}$ See Jane v Lithuania [2018] EWHC 1122 (Admin) at para 17. As regards the EU see $R O$ (C-327/18 PPU) EU:C:2018:733, 19 September 2018.

${ }^{51} R$ (Ullah) v Special Adjudicator, [2004] 2 AC 323 at para 24, per Lord Bingham.

${ }^{52}$ As to the role of the right to a fair trial in UK extradition law see Arnell, $\mathrm{P}$, The Contrasting Evolution of the Right to a Fair Trial in UK Extradition Law, [2018] 22(7) IJHR 869.

${ }^{53}$ HH v Deputy Prosecutor of the Italian Republic of Genoa, [2012] UKSC 25 at para 8 per Lady Hale.

${ }^{54}$ A rare UK reference to the distinction is found in the deportation case of $E l$ Gazzaz v Secretary of State [2018] EWCA Civ 532 where Lord Justice Sales said, in this mental health case, "... it is in fact difficult to distinguish this case from a pure medical case such as was addressed in GS (India)", at para 34, emphasis added.

55 (2013) 56 EHRR 1. See in regard to the fourth applicant in Ahmad v UK, Abu Hamza, Arnell, P., The Legality and Propriety of the Trials of Abu Hamza, (2016)

4(2) Bergen Journal of Criminal Law \& Criminal Justice 196.

${ }^{56}$ Supra note 3. 
be required. ${ }^{57}$ This former development falls short of a being a tailored rule, but rather is guidance on how the existing rules apply in mental health cases. In considering the case of one of the complainants in Ahmad v UK, Ahsan, in light of the highly restricted regime of imprisonment he faced if convicted, the ECtHR stated:

"... the assessment of whether the particular conditions of detention are incompatible with the standards of art. 3 has, in the case of mentally-ill persons, to take into consideration their vulnerability and their inability, in some cases, to complain coherently or at all about how they are being affected by any particular treatment. The feeling of inferiority and powerlessness which is typical of persons who suffer from a mental disorder calls for increased vigilance in reviewing whether the Convention has (or will be) complied with". ${ }^{58}$

In spite of this especial consideration, it was held Ahsan could be extradited. It did not appear that the psychiatric services available to him in the US prison would be unable to treat his mental health disorder. ${ }^{59}$ Again therefore, as with the oppression bar, human rights jurisprudence fails to generally and systematically recognise that mental health cases may give rise to distinct issues.

\subsection{The Forum Bar}

\subsubsection{Derivation and Meaning}

The forum bar is the third bar that may act to prevent an extradition on the basis of a mental health disorder. ${ }^{60}$ Its origins are found in what were considered exorbitant claims to jurisdiction by the United States, in particular as regards the prosecution of the so-called NatWest Three. ${ }^{61}$ The forum bar, found in ss $19 \mathrm{~B}$ and $83 \mathrm{~A}$ of the 2003 Act, provides that extradition is to be barred by reason of forum if it would not be in the "interests of justice". An extradition is not in the interests of justice if a substantial measure of the requested person's relevant activity was performed within the UK and that, having re-

${ }^{57}$ Specific and bespoke mental health assurances were sought by the ECtHR in the Aswat series of cases, mentioned below.

${ }^{58}$ Supra note 55 at para 215 , emphasis added.

${ }^{59}$ Ibid at para 224. Criticising the extradition of Ahsan is Patel, I., The Impossible Injustice of Talha Ahsan's Extradition and Detention, The New Statesman, 21 February 2013, at https://www.newstatesman.com/politics/2013/02/impossible-in justice-talha-ahsan $\% \mathrm{E} 2 \% 80 \% 99$ s-extradition-and-detention.

${ }^{60}$ See generally Arnell, P., The Forum Bar to Extradition, (2013) 24 SLT 169.

${ }^{61}$ See $R$ (Bermingham) v Director of the Serious Fraud Office [2006] EWHC 200 (Admin). 
gard to "specified matters", the extradition should not take place. There are seven such matters. Of particular relevance to mental health cases are the interests of victims and the connections between the requested person and the UK. If a judge decides the bar is satisfied he must order the person's discharge. Illustrating the operation of the bar is the case of Lauri Love. The US had sought his extradition for a number of hacking offences. Love suffered from Asperger syndrome. He invoked the forum, human rights and oppression bars. The District Judge rejected Love's arguments, and his extradition was ordered. Love successfully appealed in the first case where the bar was held to be satisfied, in Love v US. ${ }^{62}$ The High Court disagreed with the District Judge on three points, two of which related to Love's mental health. Firstly, it found that Love's extradition would not be in the interests of victims because of the high risk that he would not be fit to stand trial in the US. Secondly, the High Court placed greater weight on Love's connection to the UK. It construed "connection" to cover Love's mental health disorder and medical treatment because of the particular nature of his condition and treatment that connected him to the UK. ${ }^{63}$ It concluded that the factors against extradition, Love's mental health and the possibility of a UK prosecution, outweighed those in favour sufficiently clearly to bar his extradition.

\subsubsection{Burden and Standard of Proof and Threshold}

The relative novelty of the forum bar makes a definitive iteration of the applicable burden and standard of proof and threshold impossible. However, from the terms of the bar and the limited jurisprudence, it appears that the burden firstly falls upon the requested person, as with the other bars. ${ }^{64}$ As regards the standard of proof, the requested person must meet a "gateway" condition - namely to satisfy the judge that a substantial measure of his activity was performed in the UK, as found in s ss $19 \mathrm{~B}(2)$ and $83 \mathrm{~A}(2) .{ }^{65}$ Subsequently

${ }^{62}$ Supra note 2. His appeal was also allowed on the grounds of oppression. See Arnell, P., The Case of Lauri Love, (2018) 182(8) Criminal Law and Justice Weekly.

${ }^{63}$ Ibid.

${ }^{64}$ This was the implication in Atraskevic v Lithuania [2015] EWHC 131 (Admin) at para 13.

${ }^{65}$ Atraskevic v Lithuania, ibid at para 40. 
the court considers the "... ultimate test... whether the extradition would not be in the interests of justice". ${ }^{66}$ In applying that test the "court will be engaged in a fact-specific exercise". 67 Only those matters listed in ss $19 \mathrm{~B}(3)$ and $83 \mathrm{~A}(3)$ can be taken into account, no others. Each factor must be considered, but the judge has to "decide on the facts of the case before him. There is no ranking of importance of the various factors... a value judgment overall" has to be made. ${ }^{68}$ That value judgment has been held to be very similar to that taken in considering proportionality under article $8 .{ }^{69}$ That exercise was authoritatively set out in Poland $v$ Celinski, ${ }^{70}$ it entails an analysis of the facts as found for and against extradition followed by reasoned conclusions as to why extradition should be ordered or the defendant discharged. The threshold under the forum bar, then, is met where the factors in favour of extradition are outweighed by the interests of justice as defined by the specified matters in the bar.

\subsubsection{Mental and Physical Health Distinction}

Whether the forum bar differentiates between mental and physical health disorders is unexplored. As seen, the terms of the bar do not explicitly refer to either mental or physical health. The particular reasoning in Love $v U S$, however, may be interpreted to suggest mental health disorders are of particular import in establishing the forum bar. This follows the relevance of the requested person's connection with the UK under the bar. As noted, the High Court held that Love's mental health led to his relationship with his parents being especially important. Their necessary support strengthened his connection to the UK. Whilst persons suffering from physical health concerns undoubtedly benefit from the support of their families, in Love's case this support was of a different order. Further in Love's case, the likelihood of suicide meant that the interests of victims might not be met through extradition. These factors may support the contention that mental health disorders have been distinguished from physical illness under the forum bar. It should be noted, however, that weighing against this interpretation is Scott v US, where the

${ }^{66}$ Dibden v France [2014] EWHC 3074 (Admin), at para 18.

${ }^{67}$ Ibid.

${ }^{68}$ Atraskevic v Lithuania supra note 64 at para 14. In Scott v US [2018] EWHC 2021 (Admin) it is stated that "There is no predetermined hierarchy whereby one or more factors will have greater significance than others", at para 25.

${ }^{69}$ Scott $v$ US, ibid at para 32.

${ }^{70}$ [2015] EWHC 1274 (Admin) at para 15-17. 
requested person's connection to the UK was one of the main factors in substantiating the bar where neither mental nor physical health was at issue. ${ }^{71}$ The forum bar, then, appears to be akin to the oppression and human rights bars in not generally recognising the distinction between mental and physical health disorders. Whilst this non-recognition exists across the three bars it is possible to discern an emerging approach which provides that specific mental health-related circumstances fall under one or other bar.

\section{THE THREE BARS AND MENTAL HEALTH DISORDERS}

More than one of the three bars to extradition applicable in mental health cases are commonly put forward in the same case. ${ }^{72}$ This fact more often than not simply evidences the fact that extent of, and circumstances covered by, each bar is not clear or delimited. The extent and circumstances may overlap. Requested persons contesting extradition obviously wish to maximise the chances of their transfer being barred. The invocation of multiple bars leads to unnecessary complexity in the law. This follows, in part, from the variations between the standards of proof and thresholds under each. Greater alignment between the bars would lead to a greater degree of clarity and consistency. This could take the form of the firm acceptance of the distinction between the circumstances covered by the bars - which is emerging in the jurisprudence - or preferably fewer applicable bars. It is suggested that a single bar, that based upon human rights, is capable of acting in a manner that satisfies the interests of requested persons and that of all the other conflicting interests in extradition cases. In such a situation the law would become more focused and coherent. $^{73}$

\footnotetext{
${ }^{71}$ Supra note 68 at para 57 . This being the second case where the forum bar was successfully invoked.

${ }^{72}$ It should be noted that this overlap is not exclusive to mental health cases - it also arises in physical health cases, and indeed cases where the health of the requested person is not an issue.

${ }^{73}$ Williams, in 1992, argued that the then emergence of human rights protection in the extradition context had the effect of lessening the need for the traditional safeguards in the process, such as double criminality and the bar on the extradition of nationals, in Williams, S., Human Rights Safeguards and International Cooperation in Extradition: Striking the Balance, (1992) 2 Criminal Law Forum 191. A somewhat similar argument is put forward presently, that is the breadth and nature of the
} 
As the law stands there are three applicable bars in mental health cases, and under them a degree of discernment between them is arguably emerging. This is seen in Love v US and South Africa v Dewani. In Love v US all three bars were put forward. Whilst the High Court did not pronounce on the human rights bar, unfortunately, it did find that the forum and oppression bars went to different facets of his case. Particularly, Love's connection with the UK was instrumental in establishing the forum bar, whilst the measures put in place to prevent his suicide in the US substantiated the oppression bar. ${ }^{74}$ Somewhat similarly in South Africa v Dewani the oppression and human rights bars were linked to distinct circumstances around Dewani's extradition. Namely, the risk of suicide went to the oppression bar and South African prison conditions were measured under the human rights bar. His appeal was allow under the former, but not the latter. It must be noted that this type of approach is rare. The breadth of the bars remains opaque and overlap is common. As will be seen below, the risk of suicide is considered not only under the oppression bar but also the human rights bar. Clearly the three bars have developed in an incremental and ad hoc manner legislatively, and the relationship between them lacks authoritative judicial pronouncement. Further, the distinct issues arising in mental health disorders have not been fully and systematically accommodated across the three bars to extradition nor in regard to any single one. Cumulatively these factors militate in favour of a rationalisation of the bars to extradition applicable in mental health cases, and more generally. This lack of specific and tailored recognition under the bars is also found in the response of extradition law and practice to mental health disorders evidentially.

\section{EVIDENTIAL CHALLENGES}

The second area where extradition law has failed to consistently and adequately recognise that distinct issues may arise in mental health cases is evidence. Extradition mental health cases can often face

Footnote 73 continued

human rights bar is such to considerably weaken, if not obviate, the need for the oppression and forum bars. If a need is felt to remain then there is scope for a judicial reconsideration of the breadth of the human rights bar itself.

${ }^{74}$ Supra note 2, at para 115 . As to the latter the High Court held that those measures would "... themselves likely have a seriously adverse effect on his very vulnerable and unstable mental and physical wellbeing", ibid. 
unorthodox and difficult evidential challenges. These challenges can contribute to the complex and seemingly random nature of the law in the area. They arise from the necessity of adjudging the mental health of a requested person within the context of the process, and the breadth and nature of the subjects requiring decision. Four particular issues can be identified. These are the not uncommon occurrence of discordant diagnoses, the unseen nature of mental health disorders, the fact that certain decisions must be taken on a prospective and speculative basis and that mental health disorders arguably evolve more quickly than physical illnesses. All of these issues exist simply because a decision on the basis of mental health requires sufficient evidence to convince a court that the applicable test is met. This necessitates not only an evaluation of the requested person's mental health but may also require decision on the suitability of transfer arrangements, the nature of medical treatment, psychiatric hospitals and prison wards abroad, the likelihood of a requested person remaining unfit to plead in foreign circumstances and the nature and value of diplomatic assurances. ${ }^{75}$

\subsection{Discordant Diagnoses}

The evidential difficulties attendant to extradition mental health cases arise, in part, from mental health professionals not uncommonly disagreeing in their diagnoses and prognoses. In Polish Judicial Authority v Wolkowicz, the Court concluded that the views of the two psychiatrists in the case were irreconcilable. ${ }^{76}$ The Senior District Judge was therefore obliged to weigh up both views and come to conclusion in favour of one or the other. Notably, a different approach is taken where medical opinions conflict in fitness to plead cases. In Edwards $v U S,{ }^{77}$ the practice under the Extradition Act 1989 of allowing extradition in cases where there were differences in medical opinion over fitness to plead was argued to have changed under the 2003 Act. This was rejected. The Court held that where there was a genuine and legitimate dispute between medical experts on a requested person's fitness to plead the issue ought to be deter-

${ }^{75}$ Certain of these factors are not unique to mental health cases. Assurances and prison conditions, for example, can apply in all extradition cases.

${ }^{76}$ [2013] EWHC 102 (Admin) at para 34.

77 [2013] EWHC 1906 (Admin). 
mined by the requesting state's courts as part of the trial process. ${ }^{78}$ Where a decision is required to be taken, judges are tasked with deciding complex issues on the basis of conflicting evidence. This is, of course, not unusual. However, it is submitted that in extradition mental health cases where the consequences can be severe - indeed matters of life and death - such position may be a concern. This is because, in part, decisions are taken upon a non-criminal standard of proof. Further, affecting the decision making process is the fact that diagnosis in mental health cases is based "... in most cases entirely on behavioral criteria, defined here broadly to include cognitions (thoughts, beliefs), feelings, perceptions, desires, and actions. There is no external standard, such as a biological or psychological marker, to which the diagnostician can appeal to determine if the diagnosis is accurate". 79 This is not to suggest that the process of adjudicating upon mental illness is wanting. Nor that the participating mental health professions themselves are not robust and regulated. ${ }^{80}$ It is rather to highlight that this factor can set mental health cases apart from most physical health cases, and may be a concern in some instances.

\subsection{Unseen Disorders}

A challenge related to discordant diagnoses arising in mental health cases is based upon their non-physical, or unseen, nature. This may give rise to heightened and perhaps at times unwarranted judicial scepticism when they are put forward. In Sbar v Court of Bologna, Italy, for example, the Court noted "... the need for circumspection in evaluating the evidence when such an issue is raised in case there is a perception that raising the issue is an easy way of avoiding extra-

\footnotetext{
${ }^{78}$ Ibid at para 58. This is the position taken in the US, where competency is something to be determined by the requesting state, see Romeo v Roache (1987) 820 F.2nd 540 .

${ }^{79}$ Morse, S., Mental Health and Criminal Justice, in Luna, (ed), Reforming Criminal Justice: A Report of the Academy of Justice Bridging the Gap Between Scholarship and Reform, Vol 1, 2018, p 251 at p 254, cited at http://academyforjus tice.org/volume1/.

${ }^{80}$ Part 19 of the Criminal Practice Directions provides for expert evidence, at http://www.justice.gov.uk/courts/procedure-rules/criminal/rulesmenu-2015\#Anchor6

The Forensic Science Regulator has published a number of codes for experts including Legal Obligations, Issue 6, August 2018, at https://www.gov.uk/govern ment/publications/legal-obligations-issue-6.
} 
dition". ${ }^{81}$ The issue being raised was the risk of suicide. In Bobbe $v$ Poland, referring to the CJEU case of $C K v$ Slovenia ${ }^{82}$ the Divisional Court noted that the CJEU was conscious that those opposing removal might exaggerate their condition or make statements to medical experts designed to generate the evidence needed to defeat the threatened removal. ${ }^{83}$ It stated that the CJEU noted that in such cases the "authorities (and the courts) are bound to form their own considered judgment not only of the quality of the evidence before them but also as to the risk that it has been exaggerated for forensic ends". ${ }^{84}$ This is a risk that is less likely to exist in physical health cases. It gives rise to the possibility that courts may too readily extradite in response. Whilst of course courts must be aware that individuals facing extradition may well feign mental illness they must also appreciate the distinct nature of mental health disorders and the possible severe consequences subsequent to extradition.

\subsection{Prospective and Speculative Decisions}

Compounding the evidential challenge facing courts is the often prospective and speculative nature of the decisions that must be taken in mental health cases. ${ }^{85}$ In Maziarski $v$ Lord Advocate the High Court of Justiciary noted in this vein that "None of the psychiatrists before us was prepared to speak in terms of certainty - and we can readily understand why. As Bean $\mathbf{J}$ observed in the Wrobel v Poland [2011] EWHC B2 (Admin) '... predictions by psychiatrists cannot, as I see it, be in terms of certainty". ${ }^{86}$ Speculation is necessary on a number of questions additional to the mental health per se of the requested person. These include the efficacy of preventative measures in suicide cases, and the effect of the transfer and foreign detention. These are impossible to definitively, or in some cases even reasonably, adjudge. In Bobbe v Poland the Divisional Court noted that "... the evaluation is not based upon an ability to form a certain or absolute

\footnotetext{
${ }^{81}$ [2010] EWHC 1184 (Admin) at para 15.

82 [2017] 3 CMLR 10.

${ }^{83}$ Supra note 43 at para 64.

${ }^{84}$ Ibid.

${ }^{85}$ As an example Bensaid $v U K$ was distinguished from the physical health case of $D$ v UK where D was in the final stages of a terminal illness on the ground of Bensaid's fate being more "speculative", as per the separate opinion of Judge Bratza, Bensaid v UK, supra note 27 at para $\mathrm{O}-16$.

${ }^{86}$ [2012] HCJAC 33 at para 23.
} 
conclusion. It is based upon the realistic prospect of the requested person recovering within a reasonable time and the ability of a court ex ante to make that assessment". ${ }^{87}$ Prospective analyses of conditions abroad can also give rise to concerns arising from the rules of evidence per se. A leading Scottish case here is Kapri v HMA, ${ }^{88}$ where the High Court of Justiciary examined whether Kapri would receive a fair trial in Albania. In response to a number of reports being lodged by both sides it stated "... there is no general provision which allows the court to hold as proof of fact, merely by their production, the content of reports or other papers emanating from foreign governments, international governmental or non-governmental bodies, or academic or research institutions". ${ }^{89}$ In this regard it is important to note that the rules of evidence in England and Wales have been relaxed somewhat in extradition hearings in matters of, inter alia, human rights. ${ }^{90}$

\subsection{Fluid Nature of Certain Mental Health Disorders}

A final evidential issue that can affect the adequacy and consistency of decisions in extradition mental health cases is their at times fluid nature. Certain mental health disorders can change relatively quickly and unpredictably and, of particular concern, from the original hearing to the point of appeal. The possibility of new evidence being admitted within an appeal therefore not uncommonly arises. Governing the question are ss 27 and 29 and ss 104 and 106 of the 2003 Act. They inter alia provide that evidence which was not available at the extradition hearing may be admitted if, had it been available, it would have led the judge to decide the matter differently. The leading case here is Hungary $v$ Fenyvesi. ${ }^{91}$ Evidence that was not available at the extradition hearing was held to mean evidence that either did not exist at the time or that which was not at the disposal of the party who wished to adduce it and which he could not with reasonable diligence have obtained. The position, then, is that on appeal new evidence is often put to the Court. This fact is reasonable

\footnotetext{
${ }^{87}$ Bobbe v Poland, supra note 43 at para 40.

882015 JC 30.

89 Ibid at para 127.

${ }^{90}$ See $R$ (on the application of B) $v$ Westminster Magistrates" Court [2014] UKSC 59 , at para 23 .

91 [2009] EWHC 231 (Admin). See also FK v Germany [2017] EWHC 2160 (Admin), especially over paras $19-51$.
} 
in that it acts to facilitate the most informed and up-to-date decision. ${ }^{92}$

Overall in regard to evidence in extradition mental health cases the point that must be made is that unorthodox and difficult questions require decision. The position was aptly described by the High Court of Justiciary in Howes $v H M A$, where it said its decision on oppression and mental health was "... not however a technical issue of law, but requires the court to form an overall judgment upon the facts of the particular case", with that judgment being one which "... is likely to reflect shades of grey rather than black or white". ${ }^{93}$ The concern in the extradition context is that such decisions are affected by strong public policy reasons favouring extradition. In domestic criminal trials the burden of proof and rules of evidence operate to provide a relatively high degree of protection to the accused. This level of protection is absent where persons with mental health disorders are sought by way of extradition. Developments that can serve to mitigate certain of these evidential concerns are the production of joint medical reports and close liaison between medical professionals in both the requesting state and the UK. ${ }^{94}$ Clearly such concerted action is possible and should be taken whenever beneficial. Standing in contrast to the general lack of specific accommodation of the evidential challenges arising in mental health cases are those instances where a requested person is a suicide risk. Here, under the oppression bar, a body of jurisprudence has developed that governs the approach to be taken.

\section{SUICIDE CASES}

\subsection{Oppression and Suicide Cases}

The development of a set of suicide-related rules is one of the two ways in which extradition law has specifically recognised the distinctiveness of mental health cases. These rules have been developed

\footnotetext{
92 In Bobbe v Poland, supra note 43, it was recognised that "... the situation is 'moving' and influx... it would be an exercise in artificiality if the Court had refused to entertain and consider the new evidence", at para 28. The exceptional avenue of re-opening an appeal under Criminal Procedure Rule 50.27 also exists, see Sadowski v Poland [2018] EWHC 289 (Admin).

${ }^{93}$ Supra note 24 , at para 13.

${ }^{94}$ The former was recommended in Arshad v Malta [2014] EWHC 2515 (Admin). The latter encouraged by the Lord Chief Justice in Aswat $v$ US, supra note 3 at paras 44-45.
} 
in a series of cases where a risk of suicide is said to be a consequence of the process. ${ }^{95}$ Whilst this recognition of the risk of suicide as meriting especial consideration is appropriate, it is not beyond criticism. This is firstly because the bar in such cases is set at a particularly high level. Secondly, these suicide-specific rules have emerged and apply under the oppression bar alone, yet courts also entertain the human rights and forum bars in such cases. ${ }^{96}$ More positively, the importance of preventative measures in suicide cases has been recognised across the jurisprudence.

The rules applicable in suicide cases under the oppression bar were summarised by the Divisional Court in Polish Judicial Authority $v$ Wolkowicz. This entailed an iteration of the seven propositions set down in Turner $v$ Government of the USA. They apply where an extradition may be oppressive or unjust because of the substantial suicide risk of the requested person on account of his mental health. ${ }^{97}$ They are that the court has to form an overall judgment on the facts of the case, a high threshold must be met to satisfy the bar and that the court must assess the mental state of the individual and determine whether, if the extradition order were to be made, there would be a substantial risk he would commit suicide whatever steps were taken. Further, the court must find that the mental condition is such that capacity to resist the suicidal impulse is removed $^{98}$ and ascertain whether the requesting state has appropriate arrangements in place to address the risk. ${ }^{99}$ Finally, courts must keep in mind the important factor of the public interest

95 These include Polish Judicial Authority v Wolkowicz, supra note 76, Turner $v$ Government of the USA [2012] EWHC 2426 (Admin) and LMN v Turkey [2018] EWHC 210 (Admin). For a discussion of a number of suicide cases see Fitzgerald, W., Recent Human Rights Developments In Extradition Law and Related Immigration Law, (2013) 25 Denning Law Journal 89.

${ }^{96}$ Lauri Love's case is the sole instance of the forum bar being successfully invoked in a suicide case.

${ }^{97}$ In Polish Judicial Authority v Wolkowicz the Court refused to entertain arguments based on article 3 . In response to a suggestion that there is a possible distinction between ss 25 and 91 and article 3 it held that question does not arise and the "... issue will be determined... by the degree of risk of suicide and the measures in place to prevent suicide succeeding", supra note 76 at para 12 .

98 This has been termed a "psychologically crude and legally questionable test" by Fitzgerald, supra note 95 at p 97.

${ }^{99}$ Paradoxically in Love $v$ US the Divisional Court held that it was not the lack of effective preventative measures that substantiated the bar, rather the pervasive nature of those measures, supra note 2 at para 103. 
in giving effect to treaty obligations. ${ }^{100}$ These propositions are useful promoting consistency in suicide cases. They are also open to criticism, however, by cumulatively setting the bar so high that only in the rarest of cases will it be met.

\subsection{Human Rights and Suicide Cases}

The human rights bar is not uncommonly invoked alongside the oppression bar in suicide cases. ${ }^{101}$ In South Africa $v$ Dewani, for example, articles 2 and 3 were put forward in conjunction with the oppression bar. On the human rights point, it was held that the assurances given and the facilities available meant that there was no real and immediate threat to his life if he was extradited. ${ }^{102}$ As with human rights violations generally within extradition, the risk of suicide can relate to different aspects of the process. In Bobbe v Poland $^{103}$ the transfer was the concern. Whilst the Court accepted that a transfer could in certain circumstances amount to inhuman and degrading treatment the steps taken by the National Crime Agency (NCA) in Bobbe's case addressed the concerns. ${ }^{104}$ These included inter alia a private flight, liaison with the Polish authorities and readiness for a possible suicide attempt. A suicide case focusing upon the conditions within the requesting state and demonstrating the lack of clarity in the relationship between the human rights and oppression bars is $L M N v$ Turkey. ${ }^{105}$ Here it had been conceded that LMN's suicide risk did not provide a basis for a challenge under s 91 given the stringency of the test. On appeal however, it was successfully argued that the risk was relevant to article 3. The Divisional Court accepted that there was a high risk of suicide in the event of extradition and held that the suicide risk together with a failure to meet LMN's mental healthcare needs would in the circumstances attain the minimum standard of severity necessary to breach his article 3

${ }^{100}$ Supra note 76 at para 8.

${ }^{101}$ Prior to the Crime and Courts Act 2013 the Secretary of State retained a power to consider human rights in extradition cases. In October 2012 the then Home Secretary Theresa May exercised that power and blocked the extradition of Gary McKinnon due to his suicide risk, see http://www.bbc.co.uk/news/uk-19957138.

102 Supra note 1 at para 55, quoting the conclusion of the Senior District Judge.

103 Supra note 43.

${ }^{104}$ Ibid at para 61.

105 Supra note 95. 
rights. ${ }^{106}$ Relevant in the case was the then recent Turkish coup, the absence of formal Turkish assurances and the admission of new medical evidence as to LMN's mental health. The appeal was allowed and LMN was discharged. Mirroring the criticisms of the law made above, it is unfortunate that the suicide-case jurisprudence does not clearly distinguish between the applicability of the oppression, human rights and forum bars in the suicide context. What is called for is a rationalisation of applicable bars. Ideally, a single bar, that based upon human rights, would exist to offer protection in suicide cases. In such a case the rules akin to those developed under the oppression bar could be adopted under articles 3 and/or 8 . In the meantime, or failing a rationalisation of the bars to extradition applicable in mental health cases, a clear and consistent judicial demarcation of the applicability of the three bars is required. Both the nature of protection offered suicidal requested persons and the law itself would benefit from such a development.

\section{DIPLOMATIC ASSURANCES AND MENTAL HEALTH}

The second instance where the law has explicitly accommodated mental health-related concerns is found in its reaction to requested persons who are unfit to plead. This has taken place through diplomatic assurances. A further assurance-related development can be seen in their being tailored to address several specific mental healthrelated issues. This latter point is matter of degree rather than a specific accommodation, however, because relatively detailed assurances have been used in a variety of cases. Generally, diplomatic assurances are employed in extradition (and deportation) as a "quick, efficient and largely honoured mechanism of cooperation and regulation of multilateral and bilateral inter-State relations". ${ }^{107}$ They are designed to ensure that an individual being removed from a country will not be treated, or indeed will be treated, in a certain way. ${ }^{108}$ Diplomatic assurances have come to be used in mental health cases in a distinct way by addressing some of the issues particular to them. It

\footnotetext{
${ }^{106}$ Ibid at para 74.

${ }^{107}$ De Londras, F., Shannon, Saadi and Ireland's Reliance on Diplomatic Assurances under Article 3 of the ECHR, (2007) Irish Yearbook of International Law 79 at p 80-81.

108 Internationally, the UK has made the most determined efforts to devise and apply a rights-compliant policy of deportation with assurances. Anderson, D., and Walker, C., Deportation with Assurances, CM 9462, July 2017 at para 1.3.
} 
is this specific focus, as well as their conditional application in fitness to plead cases, that allows them to be distinguished from assurances more generally. This is to be welcomed. However their use raises concerns. These go to their seemingly ad hoc usage and questions over compliance and verifiability. ${ }^{109}$ Further, they may be criticised on account of their non-binding nature and because they might lead to the circumvention of human rights obligations in fact. ${ }^{110}$

\subsection{Conditional Nature}

A first assurance-related development in mental health cases to be noted is that they have been utilised in a conditional way. This has arisen in fitness to plead cases. As mentioned above, here the requesting state agrees to receive the requested person provisionally. If the proviso or condition is not met within a certain period of time the requesting state is obliged to return the individual to the UK. This type of assurance was used or considered in the fitness to plead cases of Dewani v South Africa and Arshad v Malta. ${ }^{111}$ In Dewani v South Africa $^{112}$ the Divisional Court considered South Africa's undertakings in this regard. They provided that Dewani would be allowed to return to the UK if, having been found unfit, the judge concludes that there is no realistic prospect of him becoming fit within eighteen months. Further, South Africa promised that if a judge embarks to determine whether Dewani committed the crime he was accused of, he would be free to return. Summers QC, for Dewani, unsuccessfully challenged several aspects of these assurances. The Divisional Court held that the undertakings bound South Africa in international law,

109 These concerns do not apply to mental health cases alone, although it may be argued that given the unique issues arising in such cases they are more pronounced here than in other contexts.

${ }^{110}$ Analysing the legal nature of diplomatic assurances in expulsion cases is Worster, W.T., Between a Treaty and Not: A Case Study of the Legal Value of Diplomatic Assurances in Expulsion Cases, (2012) 21 Minn J. Int'l L. 253. Worster concludes that diplomatic assurances do in fact possess a legally binding character. Criticising diplomatic assurances in the extradition and deportation context generally is Grozdanova, R., The UK and Diplomatic Assurances: A Minimalist Approach towards the Anti-Torture Norm, (2015) 15 ICLR 369, and defending them is Jones, K., Deportations with Assurances: Addressing Key Criticisms, (2008) 57(1) ICLQ 183.

${ }^{111}$ Supra note 94 . Here a joint medical report found it was unlikely that Arshad's mental health would improve within two years, a period longer than that which Malta had provided he would be allowed to return to the UK. His appeal against extradition was allowed.

112 Supra note 1. 
that they were properly made and that they meant that if a judge could not decide whether Dewani would remain unfit in 18 months he would be allowed to return to the UK. This conditional type of assurance was designated a "Dewani-type" assurance in Bobbe $v$ Poland - a case which touches upon one of the two general criticisms of assurances made below, their seemingly random usage.

\subsection{Specification of Assurances}

A second relevant feature of assurances in mental health cases is the degree of distinct specification that has been sought and given. ${ }^{113}$ Clearly illustrating this development is the series of cases involving Haroon Aswat, decided by the ECtHR and the English Divisional Court. Aswat was sought by the US on terrorist related offences. The process leading to his eventual extradition took almost a decade, during which the issuance of specific and tailored assurances was central. Indeed, over the period assurances were given by the US on four separate occasions. In them the US inter alia guaranteed that Aswat would not be tried by a military commission in Guantanamo Bay, nor subjected to the death penalty if convicted. ${ }^{114}$ It then guaranteed that Aswat would be able to argue he was not fit to plead, would have his competency assessed, and that that assessment could be appealed. Assurances concerning his pre-trial detention and the accommodation of his mental state if convicted were also given. ${ }^{115}$ The ECtHR considered these assurances and found them lacking. In doing so it reiterated the point that where an individual suffers from a mental health disorder "increased vigilance in reviewing whether the Convention has (or will be) complied with" is called for. ${ }^{116}$ Subsequently the US issued a further eleven undertakings addressing the concerns raised. These inter alia related to Aswat's transfer to the US, his arrival and the role of his treating clinician. Following these assurances, and a further clarification, both the Divisional Court ${ }^{117}$ and subsequently the ECtHR ${ }^{118}$ held that Aswat could be extradited.

${ }^{113}$ This is not to suggest that detailed and bespoke terms are not found in nonmental health related assurances. Rather that it appears that such assurances are more prevalent in mental health cases.

114 [2006] EWHC 2927 (Admin) at paras 25-26.

115 This is detailed in Aswat $v$ UK supra note 3 at paras 27-29.

116 Ibid at para 50 .

117 Aswat v Secretary of State, supra note 3.

118 Aswat v UK, Ap. No. 62176/14, supra note 3. 
Clearly, in this instance the "increased vigilance" led to assurances of a high degree of specification designed to address concerns arising in a mental health case.

\subsection{Varied Practice}

A criticism that can be made of assurances is their random usage and the lack of a regulatory framework governing them. ${ }^{119}$ Requests for assurances normally follow judicial concern that an extradition would engender a human rights violation in the requesting state or be oppressive. There is not clear guidance or practice governing when they will be sought or, related to this, whether there may be an obligation upon a court to seek them. This appears to be particularly relevant as regards Dewani-type assurances. In Bobbe v Poland it was agreed that Bobbe was unfit to plead. His counsel argued that the judge at Bobbe's hearing should have obtained a conditional assurance and that its absence led to his extradition being unjust and oppressive. Whilst the NCA had sought such an assurance the Polish Judicial Authority's response did not specifically and precisely address its terms. The Divisional Court held, however, there was no inevitable legal obligation to obtain assurances in the case of requested persons who were presently unfit to plead. ${ }^{120}$ The test governing the seeking of assurances, it held, was fact sensitive and only in certain circumstances was an assurance necessary. In Dewani v South Africa, the Court noted, it was relevant that the appellant had no connection to South Africa and that there was the possibility that he might be permanently unfit to plead. ${ }^{121}$ The circumstances were different in Bobbe $v$ Poland. His mental health condition was not thought permanent, and somewhat unusually, he was sought on both conviction and accusation warrants. He faced, therefore, a period of imprisonment where treatment would be available. The point made here is that in certain mental health cases assurances are sought and others not - with the distinction turning on the facts of each case. Whilst this is not unreasonable, the law lacks a clear and authoritative judicial pronouncement upon their use and content. Such a

119 That written, the ECtHR has authoritatively pronounced upon the factors a court must take into account in evaluating an assurance, in Othman v UK (2012) 55 EHRR 1.

${ }^{120}$ Supra note 43 at para 37.

121 South Africa v Dewani (No 2), supra note 1 at para 57. 
precedent would be beneficial in fostering consistency and understanding.

\subsection{Compliance and Verifiability}

A final and general concern in the area of assurances relates to requesting state compliance and verifiability. Whilst these are not specific to mental health cases they are, of course, included. In Aswat $v$ Secretary of State, for example, counsel for Aswat argued that since the management of Aswat's US trial would be under the jurisdiction of a District Judge there could be no certainty the steps proposed by other United States authorities will be fulfilled. This was summarily rejected. Although the executive gives the assurances and cannot bind the judiciary, the Court noted, "... the judiciary is part of the State which gives assurances... a judge being aware of those assurances can reasonably be expected to see that his State is not put in breach of its assurances by his or her own actions". ${ }^{122}$ Justice Mitting continued "I regard it fanciful to suggest that a judge would deliberately and for no good reason put at risk the mental health of a defendant in breach of such assurances". ${ }^{123}$ More generally, the House of Lords Select Committee on Extradition has stated that "... assurances should always be handled carefully and subjected to rigorous scrutiny... the importance of ensuring that they are genuine and effective cannot be overestimated". ${ }^{124}$ It is clear, though, that once an individual has been extradited compliance with assurances ultimately turns on the good faith of the requesting state. Verification by the UK that they have been followed, if allowed by the requesting state, is resource intensive. ${ }^{125}$ Overall, diplomatic assurances in extradition mental health cases are a mixed blessing. They may usefully ensure that requested persons are not subjected to human rights violations and oppressive and unjust treatment. They also can act to prevent an individual who is unfit to plead from remaining too long in a requesting state untried. However, their use is ad hoc and they entail a risk of non-compliance. What is needed is greater standardisation

${ }^{122}$ Supra note 3 at para 16.

${ }^{123}$ Ibid.

${ }^{124}$ House of Lords Select Committee on Extradition Law, Extradition: UK Law and Practice, supra note 5 at para 88.

${ }^{125}$ The UK has, however, made considerable efforts to ensure compliance, see Anderson and Walker, supra note 108. 
and consistency in their usage. This would almost certainly act to ameliorate at least some of their failings.

\section{CONCLUSION}

Mental health disorders in UK extradition law and practice are inconsistently and inadequately addressed. The law applying to them is multi-faceted and unnecessarily complex. It is accordingly unpredictable and seemingly random. This position flows from the law's failure to adequately recognise that mental health cases may raise issues not arising in physical health cases. That much is clear. The steps needed to improve the law, however, will not be easily achieved. This is because, in part, extradition necessarily entails an accommodation of conflicting interests. The desire to address international criminality and to adhere to international extradition agreements can be at odds with the human rights and welfare of requested persons. Simply, the cooperative and protective facets of the process cannot be wholly reconciled. Mental health disorders introduce a new and complicating factor into this equation. The facts of each case are, of course, different. Legislatively or judicially pronouncing upon even common situations is not possible. Too many variables are at play. That noted, greater clarity and consistency are achievable. Legislative simplification of the applicable bars to extradition is one way that this can be done. Ideally, the law would contain a single applicable bar to extradition based upon human rights. This would be applicable in mental health cases and generally. This is not as radical as it may seem. As the law stands the human rights bar generally accommodates circumstances also falling under the oppression and forum bars. If those bars were to be removed from the law the inherent flexibility under the human rights bar would almost certainly admit situations not presently covered. In the absence of this type of legislative intervention, an authoritative judicial pronouncement upon the circumstances in which the bars to extradition apply, and the relationship between them, is needed. This would most likely go some way in improving the law.

Overlap and inconsistency in the application of the bars to extradition in mental health cases is but one facet of the law requiring consideration. Evidentially, greater use of joint medical reports as well as regular communication between medical professionals abroad and in the UK are required. The acceptance by the law that mental health cases can give rise to distinct issues is a first step in mitigating 
the evidential concerns existing presently. This would loosen the evidential shackles in extradition cases, and permit more holistic analyses. As indeed would the acceptance of extradition hearings themselves as sui generis quasi-criminal proceedings. ${ }^{126}$ Particularly related to the need for a rationalisation of the bars to extradition are suicide cases. A single applicable bar, which failing an authoritative judicial pronouncement, is needed to clarify and standardise the rules applying to requested persons at risk of suicide. Presently, the three applicable bars serve the cause of obfuscation as much as the law and individuals concerned. A similar process of standardisation is also called for in the use and content of diplomatic assurances, especially in cases where fitness to plead is an issue. Here, as above, coherence and consistency are served through law that is settled and therefore applied similarly in different cases. Overall, it is clear that the law has tentatively recognised the particular issues arising in extradition mental health cases. This is to be welcomed. It is now time, however, for the law to take stock of that recognition and to legislatively and judicially accept that a number of the issues arising within mental health cases are distinct and demand specific and systematic regulation.

\section{OPEN ACCESS}

This article is distributed under the terms of the Creative Commons Attribution 4.0 International License (http://creativecommons.org/ licenses/by/4.0/), which permits unrestricted use, distribution, and reproduction in any medium, provided you give appropriate credit to the original author(s) and the source, provide a link to the Creative Commons license, and indicate if changes were made.

Publisher's Note Springer Nature remains neutral with regard to jurisdictional claims in published maps and institutional affiliations.

${ }^{126}$ See Arnell, P., What an Extradition Hearing is and Why it Matters, [2018] 4 Juridical Review 250. 